ks. Jan Maciej Dyduch

\title{
Omówienie działalności naukowej i kościelnej kard. prof. Mariana Jaworskiego z okazji wręczenia medalu Bene Merenti Polskiego Towarzystwa Teologicznego 24 lutego 20091
}

Bogactwo wydarzeń w życiu kard. Mariana Jaworskiego i jego niezwykle obfita działalność sprawiają, że nie jest możliwe w krótkim wystąpieniu ukazanie całościowo sylwetki wybitnego uczonego i męża Kościoła. Z konieczności więc ograniczę się tylko do niektórych jej fragmentów, za co przepraszam Laureata i uczestników uroczystości.

Urodził się 21 sierpnia 1926 roku we Lwowie. Tam ukończył szkołę podstawową i średnią, uzyskując w 1945 roku świadectwo maturalne. W tymże roku wstąpił do Wyższego Seminarium we Lwowie, które wkrótce zostało zlikwidowane przez władze sowieckie, a przez władze kościelne przeniesione do Kalwarii Zebrzydowskiej. Tam został wyświęcony na kapłana 25 VI 1950 przez arcybiskupa lwowskiego Eugeniusza Baziaka. W roku 1952 uzyskał stopień doktora teologii na Wydziale Teologicznym UJ. W roku 1953 podjął kolejne studia na Wydziale Filozofii Chrześcijańskiej KUL, które uwieńczone zostały stopniem doktora filozofii w roku 1955. W tymże roku rozpoczął wykłady z filozofii w Studium Filozoficzno-Teologicznym w Kalwarii Zebrzydowskiej, a od 1957 roku na Wydziale Teologicznym w Krakowie, usuniętym w 1954 roku z UJ, a funkcjonującym w Arcybiskupim Wyższym Seminarium Duchownym w Krakowie.

W roku 1956 został powołany przez arcybiskupa Baziaka na stanowisko jego kapelana i sekretarza osobistego. Trzeba zauważyć, że Opatrzność Boża, posługując się umysłem i sercem arcybiskupa Baziaka, skierowała

\footnotetext{
${ }^{1}$ Podczas walnego zebrania Polskiego Towarzystwa Teologicznego w dniu 24 lutego 2009 roku wręczono medal Bene Merenti - zasłużony dla Polskiego Towarzystwa Teologicznego Jego Eminencji kard. Marianowi Jaworskiemu, emerytowanemu arcybiskupowi lwowskiemu obrządku łacińskiego. Uroczystość odbyła się w auli Wyższego Seminarium Duchownego Archidiecezji Krakowskiej przy ul. Podzamcze 8 w Krakowie. Wzięli w niej udział księża kardynałowie Stanisław Dziwisz i Franciszek Macharski oraz biskupi pomocniczy archidiecezji krakowskiej: Jan Szkodoń, Jan Zając i Józef Guzdek oraz liczni członkowie towarzystwa z różnych stron Polski. Laudację poprzedzającą wręczenie medalu, której tekst zamieszczamy poniżej, wygłosił ks. prof. Jan Maciej Dyduch, rektor Papieskiej Akademii Teologicznej. Po jej wysłuchaniu prezes Polskiego Towarzystwa Teologicznego ks. prof. Kazimierz Panuś odczytał tekst dyplomu i wręczył laureatowi medal. Kard. Marian Jaworski w swym podziękowaniu zwrócił uwagę na przedziwne drogi Opatrzności, która kierowała Kościołem w trudnym czasie XX wieku. Apelował też do kapłanów, aby byli „warstwą oświeconą”, najbardziej wykształconą, kształtującą katolickie społeczeństwo w Polsce.
} 
ks. Jaworskiego na nową drogę służby Kościołowi. Podobnie było z ks. Karolem Wojtyłą, którego też arcybiskup Baziak wskazał do spełniania posługi biskupiej. Ci dwaj mężowie Kościoła darzyli się wieloletnią szczerą przyjaźnią. W roku 1966 ks. Jaworski uzyskał stopień doktora habilitowanego z nauk humanistycznych w zakresie filozofii religii na Wydziale Filozofii Chrześcijańskiej Akademii Teologii Katolickiej w Warszawie. W roku 1967 uzyskał tytuł profesora zwyczajnego na Papieskim Wydziale Teologicznym w Krakowie.

Badania naukowe ks. prof. Jaworskiego z zakresu filozofii są ukierunkowane w stronę fenomenologii religii i związanej z nią filozofii religii. $\mathrm{W}$ badaniach tych zagadnień zajmuje się Bogiem i człowiekiem. W uprawianej filozofii religii twierdzi, że nie ma „dualizmu między Bogiem filozofii i Bogiem religii, ale nie ma też całkowitej tożsamości-Bóg religii jest również Bogiem metafizyki, ale jednocześnie czymś więcej. Jest On nie tylko Bogiem w kategoriach bytowych, ale przede wszystkim Tym, którego człowiek wiary religijnej spotyka w swoim życiu, w historii, Tym, który zbawia" (M. Jaworski, Czym jest filozofia religii, „Więź” 530 (2002) nr 12, s. 75). Wybitny filozof krakowski, prof. Władysław Stróżewski stwierdza, że prof. Jaworski zasłużył poza wszelką wątpliwością na miano pioniera filozofii religii w Polsce. Bibliografia prac filozoficznych ks. Jaworskiego liczy około 100 pozycji.

Wybitna pozycja naukowa ks. prof. Jaworskiego sięga swymi korzeniami naukowego środowiska zarówno Wydziału Teologicznego UJ, jak i Wydziału Teologicznego Uniwersytetu im. Jana Kazimierza we Lwowie. Właśnie tam, w środowisku lwowskim, zrodziła się idea założenia Polskiego Towarzystwa Teologicznego. Została ona zrealizowana 23 II 1924 roku na Uniwersytecie Lwowskim. Wczoraj od tej daty minęło 85 lat - jakiś swoisty jubileusz, bo przecież nasze Towarzystwo Teologiczne jest kontynuacją tamtego założonego we Lwowie.

Znaczącą datą w życiorysie ks. prof. Jaworskiego był dzień 21 maja 1984 roku. Był to dzień jego nominacji biskupiej, za trzy miesiące będziemy świętować srebrny jubileusz tego wydarzenia. Sakrę biskupią otrzymał 23 czerwca 1984 roku w katedrze na Wawelu. Głównym konsekratorem był kard. Franciszek Macharski, współkonsekratorami biskup przemyski Ignacy Tokarczuk i biskup pomocniczy z Opola Antoni Adamiuk. Niezwykła uroczystość w katedrze zgromadziła świat polskiej nauki katolickiej i przedstawicieli wszystkich uczelni Krakowa. Zawołanie biskupie „Mihi vivere Christus est" stało się programem jego działalności biskupiej.

Jako administrator apostolski w Lubaczowie był pasterzem w niewielkiej części Archidiecezji Lwowskiej, która pozostała w granicach państwa polskiego. Zajął się odnową życia religijnego wiernych administratury. 
W tym celu urządził Kongres Eucharystyczny w 1987 roku, zaś w latach 1987-1990 synod diecezjalny. Palącą sprawą było przygotowanie należycie wykształconych i uformowanych kapłanów, dlatego wybudował w Lublinie gmach Wyższego Seminarium Duchownego, poświęcony w roku 1990. Niejako uwieńczeniem działalności pasterskiej bpa Mariana Jaworskiego w administraturze lubaczowskiej było podjęcie Ojca Świętego Jana Pawła II w Lubaczowie w dniach 2-3 czerwca 1991 roku.

Na skutek przemian polityczno-społecznych w Europie w latach 1989_ 1990 Stolica Apostolska uzyskała możliwość obsadzenia stolicy arcybiskupiej we Lwowie, która wakowała od śmierci arcybiskupa Eugeniusza Baziaka w 1962 roku. Nowym arcybiskupem został Marian Jaworski. Nominacja na arcybiskupa lwowskiego obrządku łacińskiego nastąpiła 16 stycznia 1991, zaś ingres do katedry lwowskiej 18 maja 1991 roku. W ten sposób arcybiskup Marian Jaworski przejął historyczne dziedzictwo arcybiskupów lwowskich. Było to dziedzictwo niezwykłe, ale przed nowo mianowanym arcybiskupem stanęły gigantyczne zadania. Kościół lwowski był doszczętnie zniszczony przez barbarzyński bolszewicki komunizm, który zamierzył eksterminację Kościoła katolickiego na tych terenach. We Lwowie, który w okresie międzywojennym był miastem tętniącym życiem religijnym, pozostały dwa czynne kościoły - katedra i kościół św. Antoniego, w których - w bardzo ograniczonym zakresie - władze komunistyczne pozwoliły prowadzić duszpasterstwo. Nie było właściwie nic, ani kapłanów, ani zakonów, ani zaangażowanych świeckich, ani budynków. W ciągu kolejnych lat pod przewodnictwem arcybiskupa Jaworskiego osiągnięto niezwykle wiele. Została odtworzona sieć parafialna, powstały instytucje i struktury kościelne, wybudowano czy odbudowano wiele kościołów, budynków kościelnych, powstało seminarium duchowne. Archidiecezja posiadała już własnych kapłanów, spora ich liczba była po studiach zagranicznych, odrodziły się zakony męskie i żeńskie, powstały zespoły zaangażowanych wiernych świeckich.

Do ważnych wydarzeń w życiu archidiecezji lwowskiej należy przeprowadzony tam synod archidiecezjalny w latach 1995-1997, który miał wprowadzić Kościół lwowski w dokonującą się w Kościele powszechnym odnowę posoborową. Mówił o tym arcybiskup Jaworski w katedrze lwowskiej na rozpoczęcie synodu 16 stycznia 1995 roku: „Chcemy odnowić to wszystko, co jest w tradycji naszej dobre, ale chcemy to wszystko odnowić właśnie w tym głębokim zrozumieniu ducha Soboru Watykańskiego II”. Innym niezwykle ważnym wydarzeniem była pielgrzymka Ojca Świętego Jana Pawła II do ziemi lwowskiej, którą odbył na zaproszenie arcybiskupa w dniach od 25-27 czerwca 2001 roku. Arcybiskup Jaworski uczestniczył w odbudowie episkopatu rzymsko-katolickiego na terenach włączonych do 
Ukrainy. Od 1992 roku przewodniczył Konferencji Episkopatu RzymskoKatolickiego Ukrainy. W latach 1996-1998 był administratorem apostolskim reaktywowanej diecezji łuckiej. W roku 1996 został mianowany przez Jana Pawła II konsultorem Kongregacji Wychowania Katolickiego, a w 1999 roku członkiem Papieskiej Rady ds. Rodziny. Brał udział w trzech synodach biskupów - 1991, 1995, 1998. 21 lutego 1998 roku został mianowany kardynałem in pectore. Nominacja ta została ogłoszona przez papieża 28 stycznia 2001 roku.

Kardynał Jaworski to nie tylko uczony światowej klasy i wybitny mąż Kościoła, ale także skuteczny organizator studiów kościelnych i dzielny obrońca wolności nauki katolickiej. Tymi talentami wykazał się, gdy pełnił odpowiedzialne funkcje w ramach Konferencji Episkopatu Polski. Był sekretarzem najpierw Podkomisji ds. Studiów, a następnie sekretarzem Komisji ds. Nauki katolickiej, a potem sekretarzem Rady Naukowej Episkopatu. Przywołane instytucje troszczyły się o rozwój nauki katolickiej i kościelnej w Polsce, o jej poziom i wolność oraz o uczelnie teologiczne i katolickie. Ich przewodniczącym był kardynał Karol Wojtyła, a jego najbliższym współpracownikiem sekretarz - prof. Jaworski.

Szczególne i nieocenione zasługi położył ks. prof. Jaworski dla istnienia, działania i rozwoju krakowskiej uczelni teologicznej. W roku 1974 został wybrany dziekanem Papieskiego Wydziału Teologicznego w Krakowie. Był nim do roku 1981, bowiem wówczas Ojciec Święty Jan Paweł II przekształcił Wydział w Papieską Akademię Teologiczną. Pierwszym jej rektorem został ks. prof. Jaworski, który podjął się organizowania studiów w nowej akademii. O tym można by mówić wiele, bardzo wiele. Wydaje się, że tę działalność bardzo trafnie scharakteryzował Jan Paweł II w liście z 21 VI 1984 przesłanym z okazji jego sakry biskupiej, zacytuję odnośny fragment: „W szczególności dziękuję Ci, drogi Biskupie Marianie, za wytrwałe, cierpliwe i odważne podejmowanie tego wyjątkowego dziedzictwa błogosławionej Królowej Jadwigi, dziedzictwa wielu stuleci i pokoleń, które w naszych czasach zostało szczególne zagrożone". Warto jeszcze wspomnieć o czynnym włączeniu się ks. kardynała Jaworskiego w starania o przekształcenie Papieskiej Akademii Teologicznej w Uniwersytet Papieski Jana Pawła II.

W świetle powyższych wywodów, należy decyzję zarządu Polskiego Towarzystwa Teologicznego o przyznaniu ks. kardynałowi Marianowi Jaworskiemu medalu Bene Merenti Towarzystwa, uznać za niezwykle trafną. Jest to poniekąd akt sprawiedliwości dziejowej, dokonany w 85-lecie powstania Polskiego Towarzystwa Teologicznego i 25-lecie nominacji biskupiej kardynała Mariana Jaworskiego. 